\title{
Illustrating the benefit of using hourly monitoring data on secondary inorganic aerosol and its precursors for model evaluation
}

\author{
M. Schaap ${ }^{1}$, R. P. Otjes ${ }^{2}$, and E. P. Weijers ${ }^{2}$ \\ ${ }^{1}$ TNO, Business unit Environment, Health and Safety, P.O. Box 80015, 3508 TA Utrecht, The Netherlands \\ ${ }^{2}$ Energy research Centre of the Netherlands (ECN), P.O. Box 1, 1755 LE Petten, The Netherlands
}

Received: 26 March 2010 - Published in Atmos. Chem. Phys. Discuss.: 10 May 2010

Revised: 13 September 2011 - Accepted: 13 September 2011 - Published: 8 November 2011

\begin{abstract}
Secondary inorganic aerosol, most notably ammonium nitrate and ammonium sulphate, is an important contributor to ambient particulate mass and provides a means for long range transport of acidifying components. The modelling of the formation and fate of these components is challenging. Especially, the formation of the semi-volatile ammonium nitrate is strongly dependent on ambient conditions and the precursor concentrations. For the first time an hourly artefact free data set from the MARGA instrument is available for the period of a full year (1 August 2007 to 1 August 2008) at Cabauw, the Netherlands. This data set is used to verify the results of the LOTOS-EUROS model. The comparison showed that the model underestimates the SIA levels. Closer inspection revealed that base line values appear well estimated for ammonium and sulphate and that the underestimation predominantly takes place at the peak concentrations. For nitrate the variability towards high concentrations is much better captured, however, a systematic relative underestimation was found. The model is able to reproduce many features of the intra-day variability observed for SIA. Although the model captures the seasonal and average diurnal variation of the SIA components, the modelled variability for the nitrate precursor gas nitric acid is much too large. It was found that the thermodynamic equilibrium module produces a too stable ammonium nitrate in winter and during night time in summer, whereas during the daytime in summer it is too unstable. We recommend to improve the model by verification of the equilibrium module, inclusion of coarse mode nitrate and to address the processes concerning SIA formation combined with a detailed analysis of the data set at hand. The benefit of the hourly data with both particulate and gas phase concentrations is illustrated and a continua-
\end{abstract}

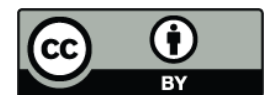

Correspondence to: M. Schaap (martijn.schaap@tno.nl) tion of these measurements may prove to be very useful in future model evaluation and improvement studies. Based on our findings we propose to implement a monitoring strategy using three levels of detail within the Netherlands.

\section{Introduction}

Secondary inorganic aerosol (SIA) contributes a large part of the particulate mass in Europe (e.g. Putaud et al., 2004). While in other regions sulphate might be more important, nitrate is the dominant component in western and central Europe (Schaap et al., 2002). Moreover, during episodes with elevated levels of particulate matter nitrate concentrations are particularly high compared to other components (e.g. Putaud et al., 2004; Weijers et al., 2011). In western and central Europe nitrate is mostly in the form of the semi-volatile ammonium nitrate (ten Brink et al., 1997; Schaap et al., 2002), whereas sodium nitrate may dominate in northern and southern Europe (e.g. Pakkanen et al., 1999). As such, particulate nitrate may be an important contributor to the aerosol direct effect over western and central Europe (Schaap et al., 2007). Furthermore, ammonium nitrate and its gaseous counterparts ammonia and nitric acid play a key role in acidifying and eutrophying deposition over Europe (Simpson et al., 2006). The understanding of the formation, transport and fate of these components is crucial to assess their role in air quality and climate change and to reduce their effects.

Within the EMEP programme the concentrations of secondary inorganic aerosol is monitored to assess the ambient concentrations and their trend in Europe (Aas et al., 2010). Furthermore, the data are used for evaluation purposes of the regional modelling work performed under the convention and within the member states (e.g. Simpson et al., 2003; Schaap et al., 2004b; Stern et al., 2008). Although

Published by Copernicus Publications on behalf of the European Geosciences Union. 
observations are required on the partitioning of the nitrogen species between the gas and aerosol phase, only a limited number of sites provide this information. Instead, a large set of daily total nitrate and ammonium data is available. Hence, the evaluation of a regional model is hampered as the partitioning between the gas and aerosol phase is hard to verify (Schaap et al., 2004b). The partitioning information is highly relevant as the non-linear nature of ammonium nitrate formation and the resulting uncertainties associated with the modelling affect the source receptor matrices which are used to develop cost effective mitigation strategies for Europe (Fagerli and Aas, 2008).

At present, available long-term monitoring data on SIA components are obtained with the standard $24 \mathrm{~h}$ sampling of aerosol by filtration and subsequent chemical analysis. This is a straightforward procedure; however, the volatile character of ammonium nitrate and the reactivity of gaseous nitric acid make these filtration methods prone to artefacts (Slanina et al., 2001). The volatilisation artefact depends on the filter material and ambient meteorological conditions like temperature and relative humidity (Chow, 1995; Hering and Cass, 1999). The evaporation artefact leads to serious underestimation of the ambient concentrations, especially during summer (Schaap et al., 2004a; Vecchi et al., 2009). Despite of the evaporation artefact the actual nitrate concentration can also be overestimated depending on the filter type. Cellulose type aerosol filters, commonly used in Europe, retain nitric acid which is thus assigned to aerosol nitrate (Schaap et al., 2004a; Keck and Wittmaak, 2006). Denuder filter packs can be used to overcome these artefacts but their use is restricted to few sites in Europe as they are costly to operate on a daily basis. To overcome these problems two systems have been developed recently in Europe, the DELTA (Tang et al., 2009) and the MARGA (Ten Brink et al., 2007; Thomas et al., 2009). The DELTA is a low cost sampler to monitor SIA components and its gaseous counterparts at a low (monthly) temporal resolution. On the other hand, the online but more labour intensive MARGA system is able to provide data for secondary inorganic aerosol and its gaseous counterparts on an hourly time resolution. Consequently, the interpretation of long term data sets obtained with the MARGA system may provide new insight in the variability and behaviour of the components. Our goal here is to illustrate the added value of hourly concentration data on ammonium nitrate and its precursors for model validation. We also propose a new monitoring strategy using a combination of the traditional and new instrumentation for the Netherlands for the purpose of model evaluation. Note that an in-depth evaluation of the model and consequent model improvement is outside the scope of this paper and will be reported in the future.

As part of the Netherlands Research Program on PM (BOP; Matthijsen et al., 2009) and continued within EMEP intensive campaigns (UNECE, 2009; Aas et al., 2010) a MARGA instrument was operated at Cabauw for a full year (Sect. 2). The LOTOS-EUROS model was applied to sim- ulate the study period at hand (Sect. 3). The model results are confronted with the measurement data (Sect. 4) to provide insight in the model performance. In Sect. 4 results on daily and seasonal variation are presented and implications discussed. Finally, we discuss a combination of instruments suitable to monitor the SIA components at different levels of detail for the purpose of model evaluation.

\section{Experimental}

A MARGA instrument was operated between the 1 August, 2007, and 1 August, 2008, at the Cabauw Experimental Site for Atmospheric Research (CESAR). CESAR (Russchenberg et al., 2005; http://www.cesar-observatory.nl) is the focal point of experimental atmospheric research in the Netherlands. The site is located in a rural area in the central part of Netherlands $\left(51.97^{\circ} \mathrm{N}, 4.93^{\circ} \mathrm{E}\right)$. It hosts a comprehensive set of instruments for meteorology, radiation as well as atmospheric chemistry, providing an excellent basis to perform additional detailed measurements.

The MARGA (Monitor for AeRosols and Gases, Applikon Analytical BV) was used to obtain a full year data set of hourly integrated data of both inorganic aerosol composition and the precursor gas concentrations. MARGA is the commercialized version of the GRAEGOR system (Thomas et al., 2009). Measured were the gases $\mathrm{NH}_{3}, \mathrm{HNO}_{3}$, $\mathrm{HONO}$, $\mathrm{HCl}, \mathrm{SO}_{2}$ as well as the inorganic $\mathrm{PM}_{10}$ components $\mathrm{NO}_{3}^{-}$, $\mathrm{SO}_{4}^{2-}, \mathrm{NH}_{4}^{+}, \mathrm{Na}^{+}, \mathrm{Cl}^{-}$(see Table 1). The sampling part of MARGA comprises a wet rotating annular denuder (WAD) for the collection of the precursor gases (Keuken et al., 1988) and subsequently a steam jet aerosol collector (SJAC) for the collection of the particulate matter (Khlystov et al., 1995). The resulting sample solutions were collected in multi channel syringe pump and per hourly cycle on line analyzed by an anion- and a cation chromatograph by direct injection. $\mathrm{Li}^{+}$ and $\mathrm{Br}^{-}$were added as internal standard. This distinguishes the MARGA from the GRAEGOR instrument, which measures $\mathrm{NH}_{4}^{+}$as the only cation, by means of a selective diffusion membrane.

The MARGA was located indoor while a Teflon coated $\mathrm{PM}_{10}$ (URG) inlet was mounted on the edge of the roof. The sampled air was drawn through a $2 \mathrm{~m}$ PE (polyethylene, 1/4" o.d.) tube towards the inlet of the WAD. A shielding PVC tube was used to maintain the sample tube wall temperature at ambient conditions by means of fan driven airflow in the PVC tube annulus preventing condensational losses towards the inner wall of the PE tube. The sampling height was $4 \mathrm{~m}$. The site was visited once a week for service purposes. Note that in this study the MARGA was used for $\mathrm{PM}_{10}$ only and no $\mathrm{PM}_{2.5}$ data were obtained. The reason was to keep the precision of the instrument as high as possible and, considering the long operation time, to reduce the amount of data gaps as the two available sampling boxes would function as each others back-up. After validation data coverage of $84 \%$ was 
Table 1. Statistical summary of the measured concentrations between 1 August, 2007, and 1 August, 2008, at Cabauw. The mean, standard deviation as well as median and quartiles are presented. $N$ indicated the number of (hourly) measurements.

\begin{tabular}{lrrrrrrrrrr}
\hline & $\mathrm{HNO}_{3}$ & $\mathrm{NH}_{3}$ & $\mathrm{NO}_{3}^{-}$ & $\mathrm{NH}_{4}^{+}$ & $\mathrm{SO}_{4}^{2-}$ & $\mathrm{SO}_{2}$ & $\mathrm{Na}^{+}$ & $\mathrm{Cl}^{-}$ & $\mathrm{HCl}$ & $\mathrm{HONO}$ \\
\hline Mean & 0.63 & 9.0 & 5.9 & 2.4 & 3.1 & 1.3 & 0.83 & 1.2 & 0.33 & 0.86 \\
Stdev & 0.36 & 7.5 & 5.2 & 2.4 & 2.6 & 1.4 & 0.86 & 1.3 & 0.51 & 0.64 \\
25th percentile & 0.41 & 4.0 & 2.2 & 0.7 & 1.5 & 0.44 & 0.25 & 0.33 & 0.12 & 0.47 \\
Median & 0.56 & 6.8 & 4.2 & 1.6 & 2.4 & 0.84 & 0.55 & 0.75 & 0.19 & 0.70 \\
75th percentile & 0.74 & 11.9 & 8.2 & 3.3 & 3.8 & 1.6 & 1.1 & 1.7 & 0.34 & 1.1 \\
$N$ & 7589 & 7603 & 7565 & 7472 & 7500 & 7539 & 6933 & 7482 & 6911 & 7601 \\
\hline
\end{tabular}

acquired as an average over the total suite of components, varying from $79 \%$ for $\mathrm{HCl}$ to $87 \%$ for $\mathrm{NH}_{3}$. The detection limit was about $50 \mathrm{ng} \mathrm{m}^{-3}$ for each component.

The quality of the method depends on the inaccuracy of the instrument itself $(<10 \%)$ (Erisman et al., 2001; Slanina et al., 2001; Weber et al., 2003) and the effect of the inlet system. The wall loss on a similar PE tube was investigated. A set of 3 used inlet tubes of the Dutch Automated Ammonia network were internally rinsed and the effluents were analyzed. Compared to the annual averaged concentration losses for $2 \mathrm{~m}$ length were calculated varying from 1 to $2 \%$ for $\mathrm{SO}_{4}^{2-}, \mathrm{HNO}_{3}+\mathrm{NO}_{3}^{-}, \mathrm{HCl}+\mathrm{Cl}^{-}$, and $\mathrm{Na}^{+}$. For $\mathrm{NH}_{3}+\mathrm{NH}_{4}^{+}$a loss less than $0.1 \%$ was found.

Another way to perform quality control is through comparison with independent co-located data. At Cabauw $\mathrm{PM}_{10}$ samples were taken and analyzed at a regular interval of two days a week (Weijers et al., 2010). In Fig. 1 we compare the results of the filter samples to the corresponding daily mean value of the MARGA for nitrate, ammonium and sulfate. The results of the two methodologies for these components compared reasonably well with regression coefficients varying from 0.9 to 1.1 , offsets less than $1 \mu \mathrm{g} \mathrm{m}^{-3}$ and correlation coefficients $\left(r^{2}\right)$ between 0.8 and 0.9 . The differences are well within the uncertainty ranges of the methods applied and we concluded that the MARGA system functioned correctly throughout the measurement period. The volatilization artifact from the quartz filters is not obviously seen, because the majority of the filters were sampled at temperatures below $20^{\circ} \mathrm{C}$. The artifact becomes significant above $20^{\circ} \mathrm{C}$ (Schaap et al., 2004a).

\section{Model simulation}

We used the regional air quality model LOTOS-EUROS v1.3 (Schaap et al., 2008) to simulate the secondary inorganic aerosol distribution over Europe and the Netherlands in particular. The LOTOS-EUROS model is a 3-D chemistry transport model aimed at simulating air pollution in the lower troposphere. The model has been used for the assessment of particulate air pollution in a number of studies directed at
PM (e.g. Schaap et al., 2004c; Stern et al., 2008; Manders et al., 2009) and its secondary inorganic components (Schaap et al., 2004b; Erisman and Schaap, 2004; Barbu et al., 2008). The model has participated frequently in international model comparisons addressing ozone (e.g. van Loon et al., 2007) and particulate matter (Cuvelier et al., 2007; Hass et al., 2003; Stern et al., 2008). For a detailed description of the model we refer to these studies. Here, we describe the most relevant model characteristics and model simulation used in this study.

Secondary inorganic aerosol formation in the model is represented through different pathways. The oxidation of $\mathrm{SO}_{2}$ to sulphate and $\mathrm{NO}_{\mathrm{x}}$ to nitric acid is described in the CBM-IV gas phase chemistry routine. Heterogeneous $\mathrm{N}_{2} \mathrm{O}_{5}$ hydrolysis on fine mode aerosols is described according to Schaap et al. (2004b). Besides the oxidation of sulphur dioxide by the $\mathrm{OH}$ radical, another important oxidation pathway, in particular in winter, is the formation of sulphate in clouds. Due to insufficient data on clouds in the meteorological input, this process is difficult to explicitly represent in the current model. Therefore, it is represented with a first order reaction constant that varies with cloud cover and relative humidity, similar to the approach followed by Matthijsen et al. (2002). The sulphuric acid formed is assumed to condense directly and is neutralised by ammonia. When sulphuric acid is completely neutralised excess ammonia (further denoted as free ammonia) can react with nitric acid under formation of semi-volatile ammonium nitrate. This equilibrium is very sensitive to ambient conditions and the precursor concentrations (Ansari and Pandis, 1998) and is calculated in LOTOSEUROS using ISORROPIA (Nenes et al., 1999). Note that the model does not include the formation of coarse mode nitrate and sulphate through e.g. reaction of nitric acid with sea salt or dust.

The model was run for the full campaign period using ECMWF meteorology. Emissions are taken from the GEMS emission database (Visschedijk et al., 2007). Seasonal and diurnal patterns were used to downscale the annual emission totals to hourly emissions for all primary components including ammonia as discussed in Schaap et al. (2004b, 2008). In the vertical the domain extends to $5 \mathrm{~km}$ above sea level and 

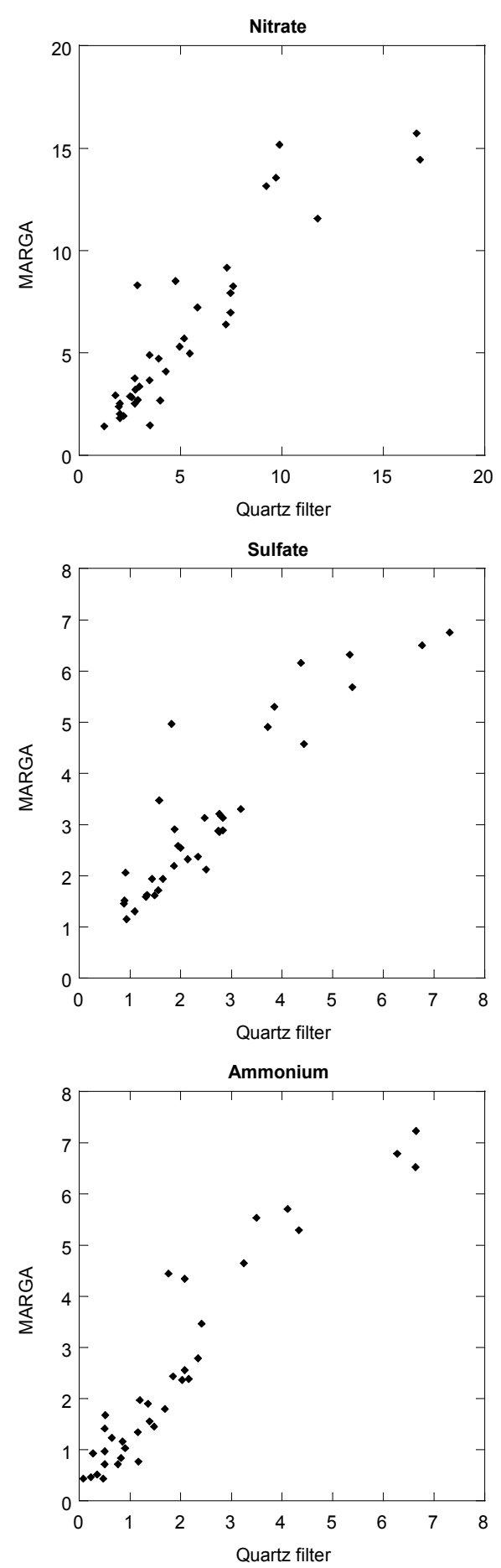

Fig. 1. Comparison between daily average concentrations $\left(\mu \mathrm{g} \mathrm{m}^{-3}\right)$ of nitrate, sulfate and ammonium as obtained by the MARGA and co-located quartz filter samples at Cabauw.

follows the dynamic mixing layer approach. There are three dynamic layers up to $3.5 \mathrm{~km}$ on top of which a fixed layer of $1.5 \mathrm{~km}$ depth is located. The lowest dynamic layer is the mixing layer, followed by two reservoir layers. The height of the mixing layer is part of the meteorological input data. The height of the reservoir layers is determined by the difference between $3.5 \mathrm{~km}$ and mixing layer height. Both layers are equally thick with a minimum of $50 \mathrm{~m}$. Within the mixing layer a surface layer with a fixed depth of $25 \mathrm{~m}$ is included in the model. The model was first run for the full European model domain on the $0.5^{\circ}$ lon $\times 0.25^{\circ}$ lat grid. Next, a nested run over the Netherlands, from 3 to $9^{\circ} \mathrm{E}$ and 49 to $55^{\circ} \mathrm{N}$, on a $0.125^{\circ}$ lon $\times 0.0625^{\circ}$ lat resolution, about $7 \times 7 \mathrm{~km}^{2}$, was performed. We have used the results of the nested simulation to compare to the detailed measurement data on both the SIA components and its gaseous counterparts.

\section{Results}

\subsection{Seasonal variation}

The observed and modelled seasonal variation is compared in Fig. 2. Note that the panels show a year from January to December meaning that the 2008 data are put before those of 2007 to arrive at a figure that is easier to interpret. For nitrate, ammonium and to a lesser extent sulphate the month to month variability is captured, albeit the levels being underestimated. The underestimation is on average $35 \%$ for nitrate and sulphate, and $25 \%$ for ammonium. Nitric acid shows a modelled distribution with a pronounced summer maximum, which is to our surprise not found in the measured data. Such a summer time maximum is observed in other countries (e.g. www.emep.int; Zimmerling et al., 2000; Perrino et al., 2001) so the different observed behaviour in the Netherlands needs further consideration. Furthermore, the observed ammonia levels are higher than those modelled. As Cabauw is located in an agricultural area with stables nearby, local contributions may affect the analysis. The assumption in the model is that the grid cells including the mixing layer are well mixed. It is therefore difficult to resolve contributions from sources with significant plumes at shorter transport distances than the horizontal grid size and/or the mixing time scale of the mixing layer $(\sim 10-15 \mathrm{~min})$. Unfortunately, several stables are locates at less than one kilometer away from Cabauw, resulting in a significant local contribution. In short, the scale at which LOTOS-EUROS is aimed is too coarse to properly account for the variation of ammonia in dense source regions. Hence, the comparison for ammonia should be interpreted with care (see discussion).

The comparison between the modelled and measured daily values for SIA (Fig. 3) shows that the model is able to capture a large part of the day to day variability in the observed concentrations. The correlation coefficients values are about 0.6 for $\mathrm{NO}_{3}^{-}$and $\mathrm{NH}_{4}^{+}$and around 0.40 for $\mathrm{SO}_{4}^{2-}$. Closer inspection reveals that low and moderately high concentrations and variability appear well estimated for ammonium and sulphate and that the underestimation predominantly takes place at the peak concentrations. For example, the four periods 

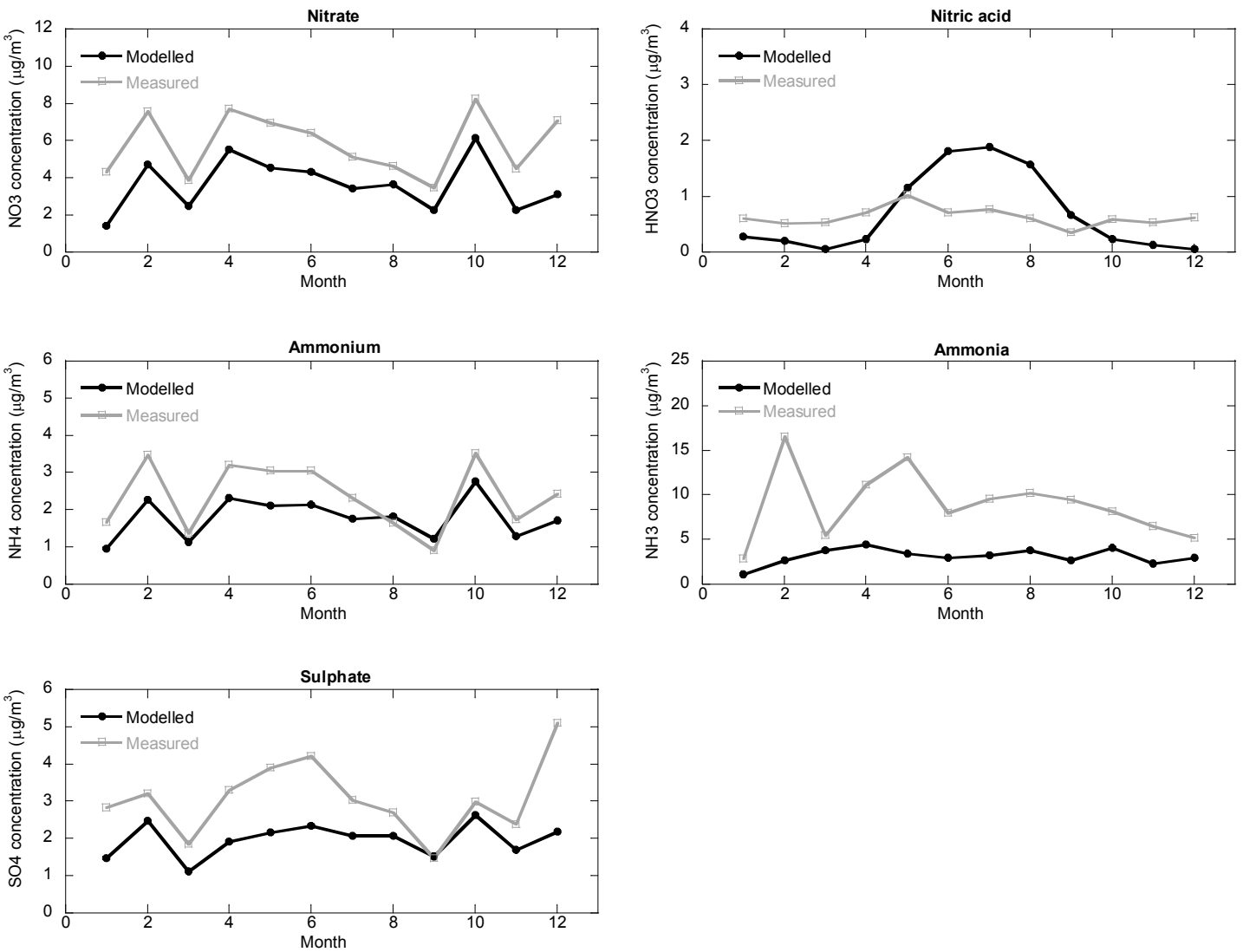

Fig. 2. Comparison of the measured seasonal cycle for nitrate, sulphate, ammonium, nitric acid and ammonia at Cabauw with $7 \mathrm{~km}$ grid resolution estimates of the LOTOS-EUROS model for this location. Note that for easy interpretation the data have been organised as if it was a year from January-December. Hence, the monthly means of January-July 2008, are put before the period August-December 2007.

with continental air masses containing sulphate concentrations above $10 \mu \mathrm{g} \mathrm{m}^{-3}$ are not captured by the model and cause the lower correlation compared to nitrate. Hence, the formation of sulphate during these episodes that occur mostly in the winter/spring needs to be addressed further. For nitrate the variability towards high concentrations is much better captured and a systematic relative underestimation remains.

We have calculated the correlation between the SIA components in the model and the observations, see Table 2. In the model the anions are strongly correlated with ammonium with coefficients of 0.98 for nitrate and 0.88 for sulphate. Nitrate is more strongly correlated with ammonium than sulphate is. Also, nitrate and sulphate are less strongly correlated than each of them with ammonium. This pattern is also found for the MARGA data adding to the conclusion that the model is able to reproduce many features of the SIA components. However, it appears that the correlations are stronger in the model than in reality, which is explainable with the role of other cat-ions than ammonium in the atmosphere that are not accounted for in LOTOS-EUROS.
Table 2. Comparison of the correlation $(R)$ between the SIA components in the LOTOS-EUROS model and in the MARGA data.

\begin{tabular}{llllll}
\hline Model & $\mathrm{SO}_{4}$ & $\mathrm{NO}_{3}$ & MARGA & $\mathrm{SO}_{4}$ & $\mathrm{NO}_{3}$ \\
\hline $\mathrm{NH}_{4}$ & 0.88 & 0.98 & $\mathrm{NH}_{4}$ & 0.75 & 0.93 \\
$\mathrm{NO}_{3}$ & 0.75 & & $\mathrm{NO}_{3}$ & 0.59 & \\
\hline
\end{tabular}

\subsection{Diurnal variation}

For the first time the LOTOS-EUROS model can be evaluated on an hourly resolution with both the particulate components as well as their gas phase counterparts which together determine the equilibrium for ammonium nitrate. The comparison of the hourly data is illustrated in the form of time series in Figs. 4 and 5. A limited statistical comparison is given in Table 3 . These time series show the general features as described above. In other words, they show the underestimation but good correlation for nitrate as well as the sulphate episodes not captured in spring. On the other hand, much 

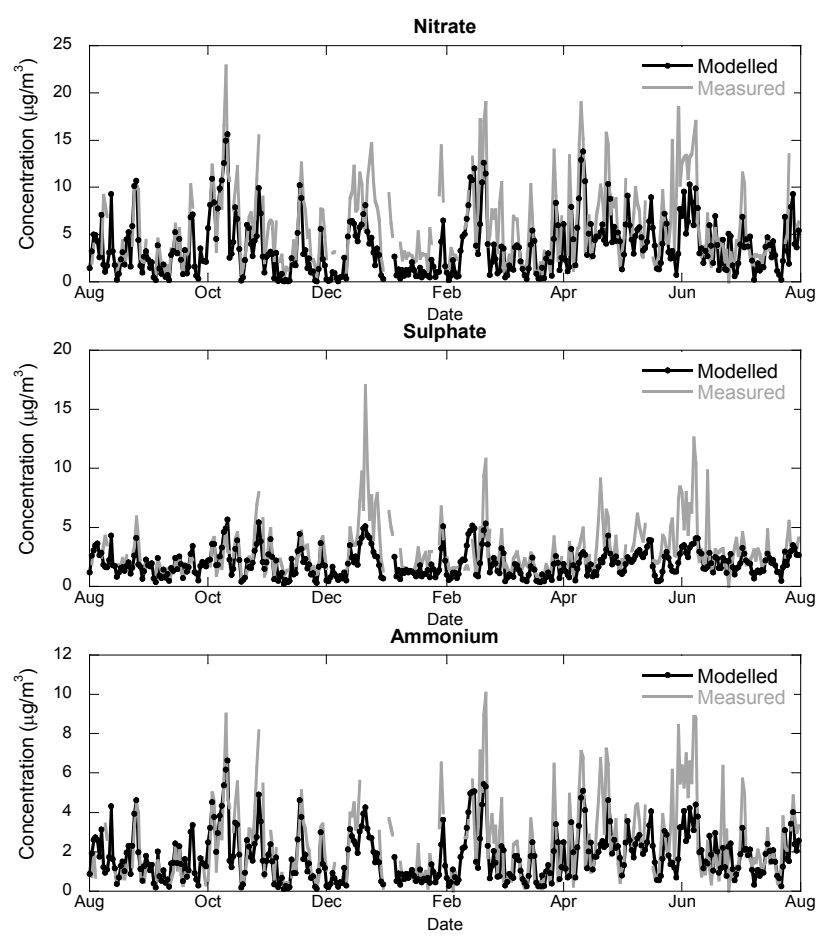

Fig. 3. Comparison of the measured (grey) day to day variability for nitrate, sulphate and ammonium at Cabauw with $7 \mathrm{~km}$ grid resolution estimates (black) of the LOTOS-EUROS model for this location and the full year.

Table 3. Statistical comparison between modelled and measured concentrations. Modelled average and standard deviation are given for each component as well as the correlation $(R)$, bias and root mean squared error (RMSE) in comparison to the measurements.

\begin{tabular}{lrrrrr}
\hline & $\mathrm{HNO}_{3}$ & $\mathrm{NH}_{3}$ & $\mathrm{NO}_{3}^{-}$ & $\mathrm{NH}_{4}^{+}$ & $\mathrm{SO}_{4}^{2-}$ \\
\hline Mean & 0.70 & 3.1 & 3.7 & 1.8 & 2.0 \\
Stdev & 1.3 & 3.0 & 3.5 & 1.4 & 1.2 \\
Bias & 0.07 & -5.9 & -2.2 & -0.60 & -1.1 \\
Correlation & 0.44 & 0.30 & 0.69 & 0.71 & 0.57 \\
RMSE & 1.2 & 9.3 & 4.3 & 1.8 & 2.5 \\
\hline
\end{tabular}

more detail is visible in the time series and we notice that the model is able to reproduce many features, also at the intraday scale. As a consequence, the correlation on an hourly basis is better than at a daily basis.

To further investigate the behaviour of the model on an hourly basis we have compared the (annual) average diurnal variation against that in the measurements, see Fig. 6 . The measured sulphate variation over the day is relatively flat, with a tendency to a daytime maximum. LOTOS-EUROS yields a flat distribution as well but has a tendency to a slight daytime minimum. We conclude that the formation of sul-
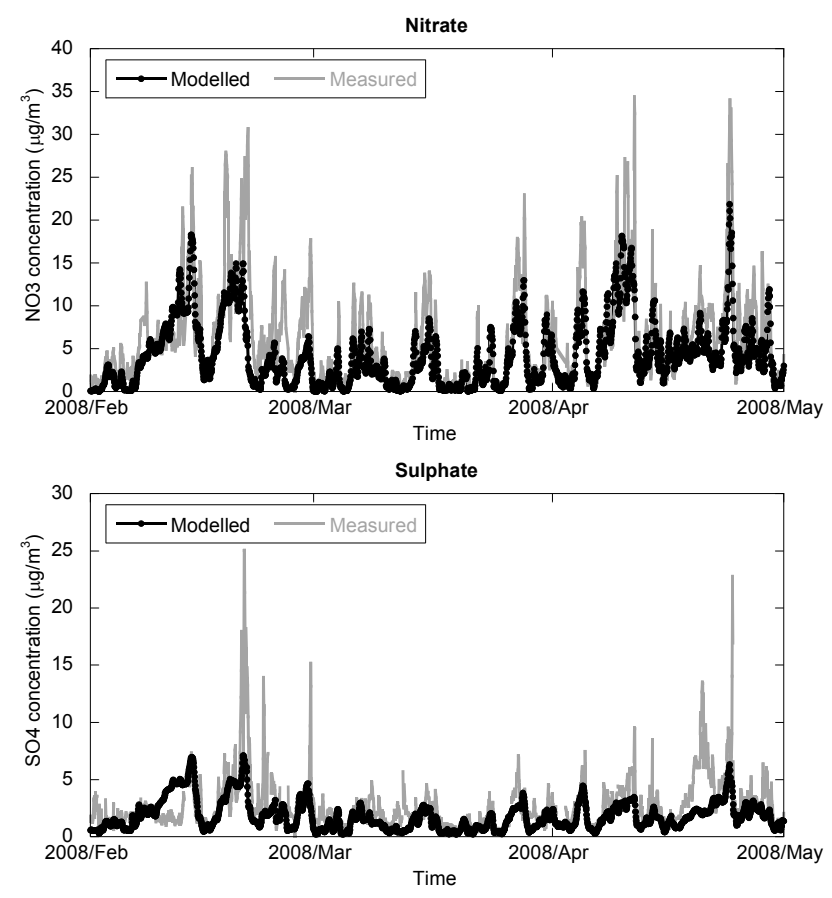

Fig. 4. Comparison of the measured (grey) hourly concentrations of nitrate and sulphate at Cabauw with $7 \mathrm{~km}$ grid resolution estimates (black) of the LOTOS-EUROS model for February-March-April, 2008.
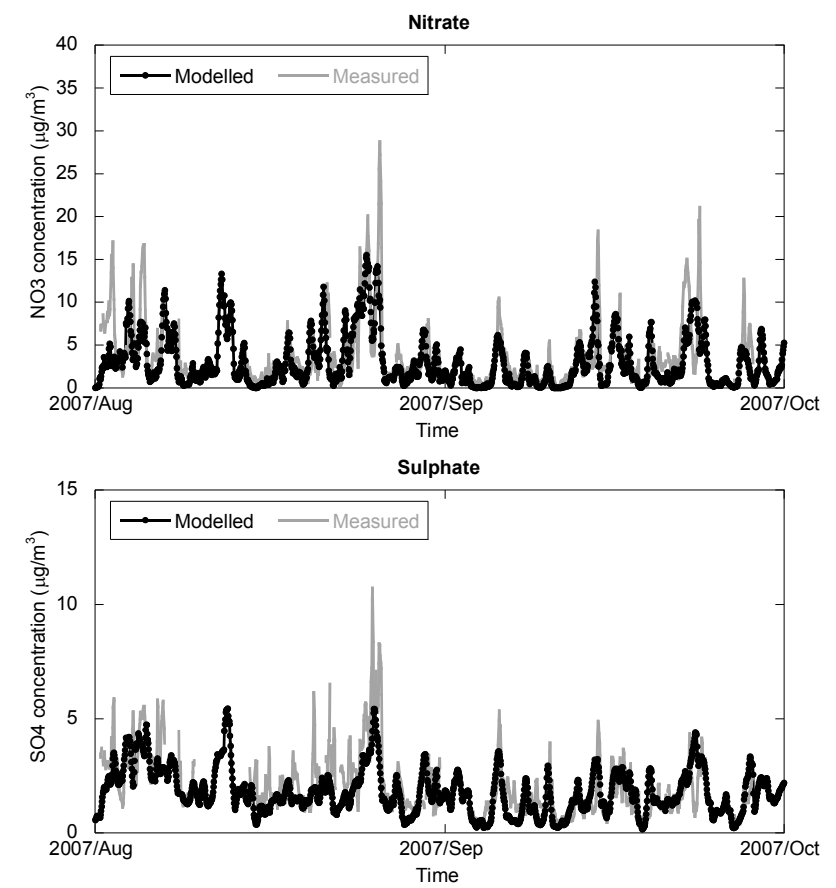

Fig. 5. Comparison of the measured (grey) hourly concentrations of nitrate and sulphate at Cabauw with $7 \mathrm{~km}$ grid resolution estimates (black) of the LOTOS-EUROS model for August-September 2007. 

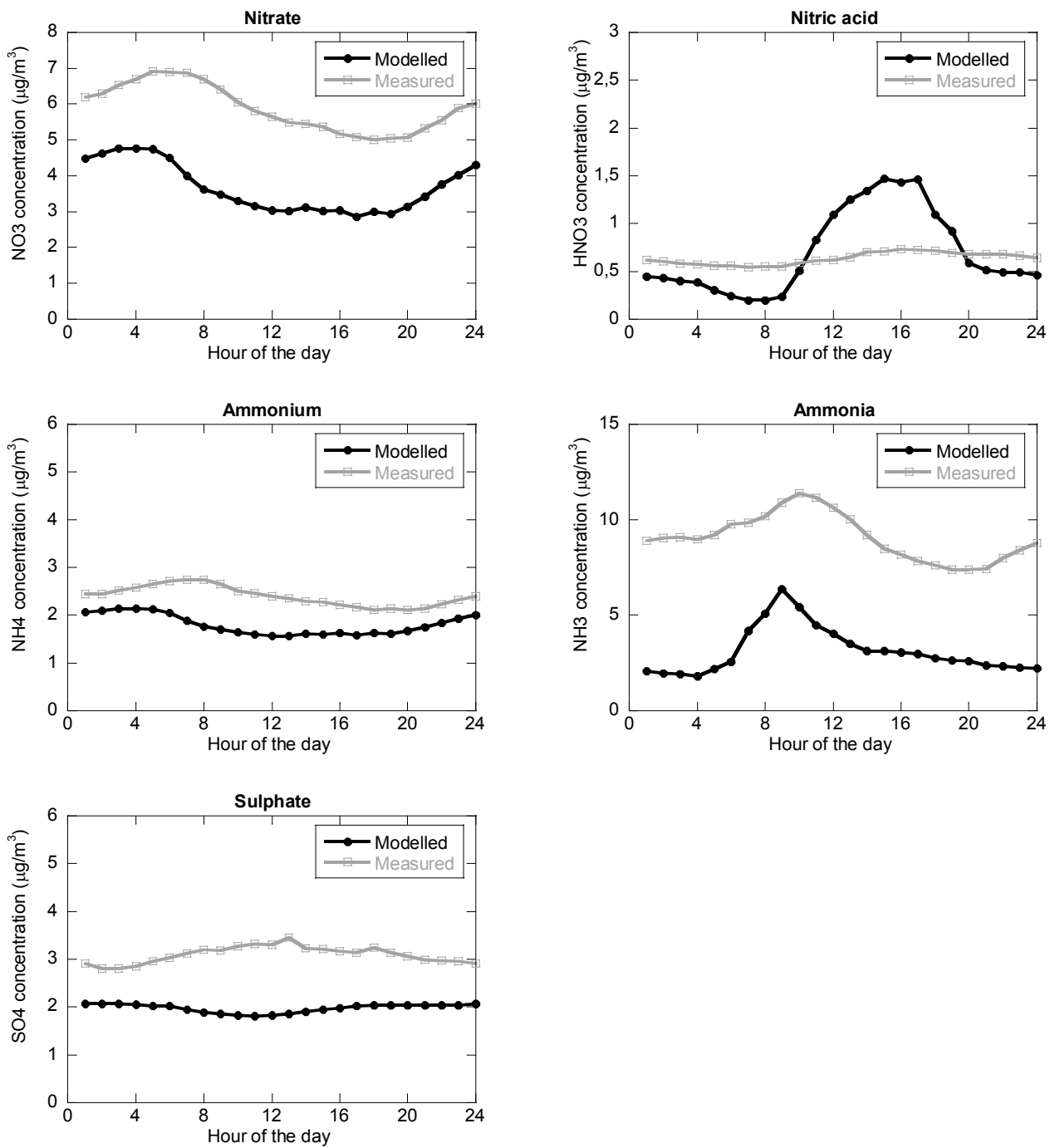

Fig. 6. Comparison of the measured (grey) diurnal cycle for nitrate, sulphate, ammonium, nitric acid and ammonia at Cabauw with $7 \mathrm{~km}$ grid resolution estimates (black) of the LOTOS-EUROS model for this location.

phate as well as the sinks should be investigated to improve the absolute level and especially the peak values rather than investigating the diurnal variability.

Although the absolute level of nitrate is underestimated the diurnal variation is rather well captured. Maximum concentrations occur in the early morning after a night time build up. Both the model and the observations show a daytime minimum, which is driven in the model by the increase in mixing layer height and the higher instability of ammonium nitrate at high temperatures. It appears that the decrease in nitrate (and also ammonium) in the early morning starts 1-2 earlier than in the observations. This may be due to the three hourly meteorological data used by the model which are interpolated to acquire hourly values. Hence, the timing of the rise of the mixing layer is not well represented and occurs gradually between 06:00 and 09:00 a.m. GMT in summer, whereas in reality it may be characterised by a more rapid mixing layer growth that occurs later in the morning.

The comparison for nitric acid and ammonia reveals an interesting picture. The model predicts a strong diurnal variation of nitric acid. In summer a strong daytime maximum is modelled up to an average concentration of about $3.5 \mu \mathrm{g} \mathrm{m} \mathrm{m}^{-3}$. During winter, the model simulates much lower values than in summer with a daytime minimum, which is associated with a daytime maximum in ammonia. The measurements on the other hand yield a much lower dependency on season. The measured concentrations in summer are only little higher than in winter (Fig. 2). Moreover, the measurements indicate a flat diurnal variation in winter and only a slight daytime maximum in summer. For ammonia the diurnal variation is roughly in line with observations despite the absolute concentrations being too low as discussed above. The 
discrepancies between modelled and measured variability on the seasonal and the diurnal scale need to be addressed taking into account several (interacting) processes that influence the concentrations and their dependencies. Below, we address the evaluation of the equilibrium assumption incorporated in the model in more detail.

\subsection{Testing the equilibrium module}

We have identified that the model does not reproduce the seasonal and diurnal cycle of nitric acid. The lower modelled nitric acid concentrations than those measured indicate that, even with an underestimation of ammonia levels, the ammonium nitrate in the model is significantly more stable than in reality in winter. For the summer, it is difficult to draw conclusions on this aspect as the concentration product of the underestimated ammonia and the overestimated nitric acid may be more inline with the measured values. Hence, we have addressed the partitioning module in the model separately by confronting the predicted partitioning based on the measured total nitrate, total ammonium, sulphate and meteorological data to the observed partitioning. We include only data with a total ammonium to sulphate ratio above 3 to ensure the presence of free ammonia and ammonium nitrate formation.

In Fig. 7 we compare the modelled and measured diurnal cycle of nitrate and nitric acid for December and July. For December, the predicted nitric acid concentration by the equilibrium module is much lower than observed throughout the day, whereas nitrate is (by definition) overestimated by the same amount. This behaviour is observed for all months from October to April. In the other (summer) months, however, a different picture arises. During the night the predicted stability is too high, as for the winter period. During daytime, on the other hand, the predicted nitric acid concentration is much higher than measured. The same underestimation of nitrate indicates that the ammonium nitrate is too unstable in the equilibrium module. This interpretation is valid under the assumption that the ammonium nitrate in the atmosphere is in equilibrium with its gaseous counterparts. Thus, our results indicate that the equilibrium assumption is not valid and/or that the equilibrium module is not able to describe the partitioning correctly under the conditions encountered in the Netherlands.

Another potential explanation of the summer time under prediction of day time aerosol nitrate may be associated with the role of sea salt. Formation of sodium nitrate through reaction of nitric acid and sea salt results in a stable aerosol component as well as a depletion of chloride. On average, the measurement data show a chloride depletion of about $15 \%$. In fact, the absolute amount of chloride depletion is higher in marine and nitrate poor air masses compared to continental, nitrate rich air masses. In Fig. 8a we show the average diurnal cycle of sodium and chloride for July. Moreover, we show the diurnal cycle of the chloride depletion expressed in potential nitrate mass. The depletion shows a minor diurnal
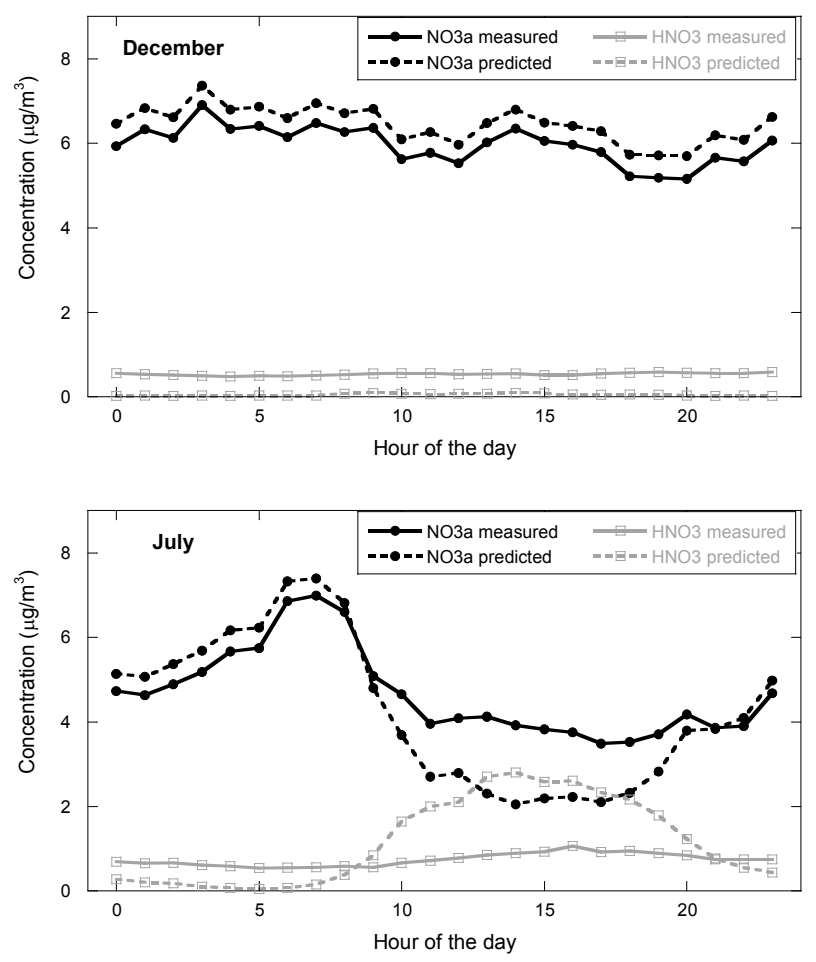

Fig. 7. Comparison between the measured partitioning of nitrate between the aerosol and gas phase at Cabauw for December (upper panel) and July (lower panel) with that predicted using ISORROPIA. For both months the average diurnal cycle is given. All hourly averages consist of at least 23 data points.

cycle with a tendency to be higher in the late afternoon and evening. The potential contribution of sodium nitrate is in the range of $1-1.5 \mu \mathrm{g} \mathrm{m}^{-3}$. In comparison to the observed difference between predicted and observed day time nitrate concentrations the potential amount of sodium nitrate may explain half of the difference. Note, that in case of an important contribution of sodium nitrate the observation that the predictions during the night and in winter are not in line is amplified. To investigate whether the potential sodium nitrate is realistic the molar balance between ammonium and the sum of nitrate and sulfate $\left(\mathrm{NH}_{4} /\left(2 \cdot \mathrm{SO}_{4}+\mathrm{NO}_{3}\right)\right.$ is addressed in Fig. 8b. In case of ammonium nitrate and ammonium sulfate the ratio should theoretically be 1 . Based on the measurements the average ratio ranges between 0.93-1.07 and shows a slight minimum during day time. Assuming the potential sodium nitrate to be present in reality the ratio increases significantly to 1.06 and 1.21 resulting in a net excess of ammonium. Based on these results we feel that some nitrate will be present in the form of sodium nitrate, but not to the full potential extend as estimated above and we conclude that the difference between day time observed and predicted nitrate can not be largely explained by the formation of sodium nitrate. 

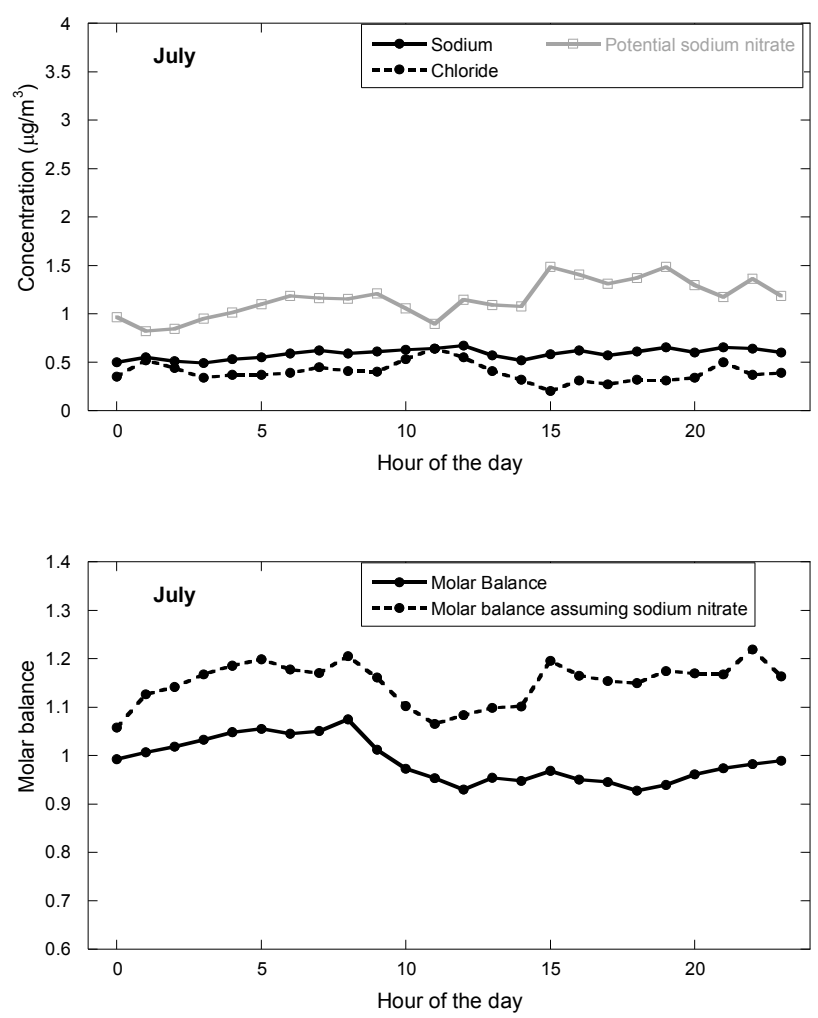

Fig. 8. (a) Measured diurnal cycle of sodium and chloride concentrations as well as that of the potential sodium nitrate concentration during July at Cabauw. The potential sodium nitrate was calculated under assumption that all sodium derives from sea salt and all chloride depletion is caused by reaction with nitric acid; (b) observed diurnal cycle of the molar balance between ammonium and the sum of nitrate and sulfate and the change in the balance by assuming the potential sodium nitrate (see main text).

\section{Discussion and conclusions}

The one-year MARGA data set acquired at Cabauw provides a unique case for model validation. The detailed and highly resolved data provide new insights in the intra-day variability of the inorganic aerosol and its precursors. Therefore, they are highly useful for model evaluation. We have identified that the LOTOS-EUROS model underestimates the concentrations of secondary inorganic aerosols at Cabauw. The same finding was obtained comparing the model results to one year data sets with filter measurements obtained at 5 sites, including Cabauw, throughout the Netherlands (Weijers et al., 2011). Note that this is not consistent with earlier comparisons against Dutch monitoring data (e.g. Manders et al., 2009). This is explained by the consistently higher SIA concentrations measured in this study using both the MARGA and the filter based $\mathrm{PM}_{10}$ samples compared to those obtained with dedicated LVS devices in use in the national network up to 2008 (Weijers et al., 2010; Hafkenscheid et al., 2010) against which our and other models have al- ways been evaluated. Hence, the higher than expected levels of SIA combined with the possibility to evaluate the performance on a diurnal basis calls for a renewed attention to the modelling of SIA in the Netherlands.

The concentration of ammonium nitrate is sensitive to the sulphate concentration, concentrations of the precursor gases as well as the meteorological conditions $(T, \mathrm{RH})$. This makes the diagnosis of the origin of an underestimation difficult as one needs to verify the source strengths of precursors, chemical production of sulphate and nitric acid, the equilibrium between ammonium nitrate and its gaseous counterparts as well as the sinks for all components involved. We have illustrated that the experimental data obtained within the campaign are very useful to evaluate the cycles of these components in the model. Evaluation of the seasonal and diurnal cycles showed that they are generally captured by the model for the particulates. On the other hand, the seasonal and diurnal variability of nitric acid in the model is much higher than in reality. The results hint at shortcomings in the equilibrium approach in combination with well known uncertainties associated with among others: meteorological parameters such as boundary layer height and stability, spatial and temporal emission patterns, cloud or multi-phase chemistry, particle dry deposition, ammonia compensation point and the effective emission height of large point sources. Though, an in-depth evaluation of the model and consequent model improvement is outside the scope of this paper, we have touched upon the modelling of the thermodynamic equilibrium in more detail as the MARGA instrument provides a unique potential to evaluate it.

The MARGA observations were used to evaluate the calculated equilibrium between particulate ammonium nitrate and gaseous nitric acid and ammonia. We have found that the thermodynamic equilibrium module produces a too stable ammonium nitrate in winter and during night time in summer, whereas during the daytime in summer it is too unstable. Earlier studies have also identified an underestimation of the particulate nitrate concentrations during summer and daytime (Moya et al., 2001; Fisseha et al., 2006; Morino et al., 2006). In contrast, a number of studies have shown that the predicted equilibrium is generally in accordance with observations (Zhang et al., 2003; Takahama et al., 2004; Yu et al., 2005), though also in these studies significant discrepancies between measured and predicted partitioning have been observed. The reported results have been obtained over a range of pollution and climatic regimes. The contradicting results indicate that it is necessary to further test thermodynamic gas-aerosol partitioning modules using experimental data for a wide range of climatic and pollution conditions.

The equilibrium module can be tested directly only when the equilibrium assumption is valid. Our results indicate that the equilibrium assumption is not valid and/or that the equilibrium module is not able to describe the partitioning correctly under the conditions encountered in the Netherlands. In the first case, the equilibrium should be calculated 
dynamically in the model to account for the impact of other processes on the concentrations. For example, it has been has been postulated that the relative abundant nitrate during daytime in summer may partly be due to transport of nitrate richer air from the upper parts of the boundary layer to the ground (Morino et al., 2006).

Based on the observed sodium concentrations the estimates sea salt contribution to sulphate is estimated at $6 \%$, inline with the results for several stations in the Netherlands (Weijers et al., 2011). This number is considerably lower than the bias observed between the model and the measurements and will not lower the underestionation of sulfate peak values as sulfate and sea salt concentrations show an anti correlation. The filter measurements (Weijers et al., 2011) indicate that coarse mode nitrate concentrations at Cabauw are on average $1.0 \mu \mathrm{g} \mathrm{m}^{-3}$. This number is in line with the potential coarse mode nitrate estimated in Fig. 8. However, the comparison is complicated by the fact that the chloride depletion at the filters are in the order of $25 \%$ and therefore higher than that obtained from the MARGA. Hence, we can not rule out that part of the chloride depletion occurred at the filter itself which means that the number should be regarded as an upper limit. Also note that the sodium concentrations in continental air masses may derive partially from non-marine sources such as wood combustion (van Loon et al., 2005). Hence, the difference between day time observed and predicted nitrate by the thermodynamic module during summer can not be largely explained by the formation of sodium nitrate. These considerations show that the matter at hand is complex. Incorporation of the formation of coarse mode nitrate in the LOTOS-EUROS model appears to be needed as it may improve our understanding of the processes involved and contribute to the lowering of the underestimation of nitrate and (partly) the overestimation of nitric acid.

Regional models tend to underestimate the ammonia concentrations at regional background sites. As Cabauw is located in an agricultural area local emission contributions for ammonia can not be excluded. Therefore, the presented comparison to the data is not representative due to the location in a "hotspot" area. Hence, for ammonia observations in nature areas should be used for validation. Due to the sensitivity of the ammonium nitrate formation to the ambient ammonia concentrations an hourly resolved MARGA dataset obtained in a nature area would be very useful to verify our conclusions on the equilibrium module and the variability in nitric acid. Note that new approaches to tackle long lasting challenges in ammonia modelling such as the incorporation of the compensation point in the deposition routine are under development. MARGA data may prove very useful to evaluate the impact of these approaches on ammonia concentrations as well as the associated particulate concentrations.

\section{Recommendation for monitoring in the Netherlands}

The issue of the representativeness of the monitoring data in combination with the different behaviour of pollutants as function of conditions highlights the need of measurement locations in different environments. The latter is generally recognised. We have shown the benefit of the hourly data with both particulate as well as gas phase concentrations and a continuation of these measurements may prove to be very useful in future model evaluation and improvement studies. However, the MARGA is labour intensive and its use is probably restricted to a number of sites of special interest. Hence, a monitoring strategy for SIA and its gaseous counterparts needs to find an optimal balance between the required information and the resources to obtain the data. Hence, a suite of methodologies should be applied. We propose a general combination of methodologies for the purpose of model evaluation for SIA, taking into account the requirements of monitoring for Particulate Matter and acidification and eutrophication.

We propose to use a monitoring strategy within the Netherlands employing a combination of the MARGA system, a filter based approach used for the determination of $\mathrm{PM}_{2.5}$ and $\mathrm{PM}_{10}$ mass concentration and a modified DELTA sampler. The DELTA (Tang et al., 2009) could be used as a backbone of the network. It provides monthly mean concentrations of the same species as the MARGA. However, Gehrig et al. (2009) have shown that losses may occur in the original tubing of the sampler. Hence, we propose to use the modified DELTA sampler (Gehrig et al., 2009) in combination with $\mathrm{NaCl}$ impregnations of the denuder and filter for the collection of nitric acid and nitrate. The latter is to avoid possible artefacts from absorption and consequent oxidation of $\mathrm{HNO}_{2}$ (Pakkanen et al., 1999; Tang et al., 2009). This system is cost efficient and can be used at a significant number of sites in different environments. In addition, dedicated passive sampling for ammonia is very valuable to resolve the high gradients in this component over the country (Duyzer et al., 2001). Daily concentration data on the particulate SIA components can be derived from the analysis of the samples taken using the reference methodology for $\mathrm{PM}_{\mathrm{x}}$. Although the reference methodology is prone to losses of ammonium nitrate (Vecchi et al., 2009), the data are consistent with the PM measurements adding to the assessment of the mass closure for $\mathrm{PM}_{\mathrm{x}}$. Finally, at a small number of sites the MARGA system can be operated for detailed monitoring. These sites could also be used to test emerging measurement techniques such as optical techniques for measuring ammonia (von Bobrutski et al., 2010). Simultaneous monitoring at these central sites is necessary to benchmark the performance of the systems against each other and to interpret the data from the full monitoring program.

Similar considerations would also apply to the monitoring strategy within other countries or international monitoring strategies. From this perspective it is worthwhile to mention 
that a network of DELTA samplers has been operational in Europe with Nitro-Europe (Tang et al., 2009) and that long term monitoring using the MARGA has commenced at locations such as Melpitz, Helsinki and Auchencorth (Twigg et al., 2011).

Acknowledgements. The authors are grateful for the support through the Netherlands Research Program on Particulate Matter (BOP), funded by the Netherlands Ministry of Housing, Spatial planning and the Environment (VROM).

Edited by: M. Sutton

\section{References}

Aas, W., Tsyro, S., Fagerli, H., Yttri, K. E., Gehrig, R., Nemitz, E., Otjes, R., Perrino, C., Putaud, J.-P., Perez, N., and Spindler, G.: Lessons learnt from the first EMEP intensive measurement periods, submitted, 2010.

Ansari, A. S. and Pandis, S. N.: Responce of Inorganic PM to Precursor Concentrations, Environ. Sci. Technol., 32, 2706-2714, 1998.

Barbu, A. L., Segers, A. J., Schaap, M., Heemink, A. W., and Builtjes, P. J. H.: A multi-component data assimilation experiment directed to sulphur dioxide and sulphate over Europe, Atmos. Environ., 43, 1622-1631, 2009.

Chow, J. C.: Measurement Methods to Determine Compliance with Ambient Air Quality Standards for Suspended Particles, J. Air Waste Manage. Assoc., 45, 320-382, 1995.

Cuvelier, C., Thunis, P.,Vautard, R., Amann, M., Bessagnet, B., M. Bedogni, M., Berkowicz, R., Brandt, J., Brocheton, F., Builtjes, P., Coppalle, A., Denby, B., Douros, G., Graf, A., Hellmuth, O., Honoré, C., Hodzic, A., Jonson, J., Kerschbaumer, A., de Leeuw, F., Minguzzi, E., Moussiopoulos, N., Pertot, C., Pirovano, G., Rouil, L., Schaap, M., Stern, R.,Tarrason, L., Vignati, E., Volta, M., White, L., Wind, P., and Zuber, A.: CityDelta: A model intercomparison study to explore the impact of emission reductions in European cities in 2010, Atmos. Environ. 41, 189-207, 2007.

Duyzer, J., Nijenhuis, B., and Weststrate, H.: Monitoring and modelling of ammonia concentrations and deposition in agricultural areas of the Netherlands, Water Air Soil Pollut., 1, 131-144, 2001.

Erisman, J. W. and Schaap, M.: The need for ammonia abatement with respect to secondary PM reductions in Europe, Environ. Pollut., 129, 159-163, 2004.

Erisman, J. W., Otjes, R. P., Hensen, A., Jongejan, P. A. C., Bulk van den, P., Khlystov, A., Möls, J. J., and Slanina, J.: Instrument development and application in studies and monitoring of ambient ammonia, Atmos. Environ.,35, 1913-1922, 2001.

Fagerli, H. and Aas, W.: Trends of nitrogen in air and precipitation: Model results and observations at EMEP sites in Europe, 19802003, Environ. Pollut., 154, 448-461, 2008.

Fisseha, R., Dommen, J., Gutzwiller, L., Weingartner, E., Gysel, M., Emmenegger, C., Kalberer, M., and Baltensperger, U.: Seasonal and diurnal characteristics of water soluble inorganic compounds in the gas and aerosol phase in the Zurich area, Atmos. Chem. Phys., 6, 1895-1904, doi:10.5194/acp-6-1895-2006, 2006.
Gehrig, R.: Aerosol- und gasförmige Stickstoffverbindungen an den NABELStationen Rigi, Payerne und Magadino - Weiterentwicklung und Validierung der Minidenudermethode, Empa report Nr. 203'056/12, EMPA, Dübendorf, Switzerland, 2009 (in German).

Hafkenscheid, T. L., Hoogerbrugge. R., and Stefess, G.: Vergelijkend onderzoek van methoden voor de bepaling van metalen in buitenlucht: Oude methode (MVS) vs. nieuwe methode (PM10), RIVM Report 680708008, Rijksinstituut voor Volksgezondheid en Milieu, Bilthoven, 2010 (in Dutch).

Hass, H., van Loon, M., Kessler, C., Stern, R., Matthijsen, J., Sauter, F., Zlatev, Z., Langner, J., Foltescu, V., and Schaap, M.: Aerosol modelling: Results and Intercomparison from European Regional-scale modelling systems, Special Rep. EUROTRAC-2 ISS, Munchen, 2003.

Hering, S. and Cass, G.: The magnitude of bias in the measurement of $\mathrm{PM}_{2.5}$ arising from volatilisation of particulate nitrate from Teflon filters, J. Air Waste Manage. Assoc., 49, 725-733, 1999.

Keck, L. and Wittmaack, K.: Simplified approach to measuring semivolatile inorganic particulate matter using a denuded cellulose filter without backup filters, Atmos. Environ., 40, 71067114, doi:10.1016/j.atmosenv.2006.06.027, 2006.

Keuken, M. P., Schoonebeek, C. A. M., Vanwensveenlouter, A., and Slanina, J.: Simultaneous Sampling of NH3, HNO3, HCl, SO2 and $\mathrm{H} 2 \mathrm{O} 2$ in Ambient Air by a Wet Annular Denuder System, Atmos. Environ., 22 2541-2548, 1988.

Khlystov, A., Wyers, G. P., and Slanina, J.: The Steam-Jet Aerosol Collector, Atmos. Environ., 29, 2229-2234, 1995.

Manders, A. M. M., Schaap, M., and Hoogerbrugge, R.: Testing the capability of the chemistry transport model LOTOS-EUROS to forecast $\mathrm{PM}_{10}$ levels in the Netherlands, Atmos. Environ., 43, 4050-4059, 2009.

Matthijsen, J., Sauter, F. J., and de Waal, E. S.: Modelling of particulate matter on a European scale, edited by: Keller, J. and. Andreani-Aksojoglu, S, Proceedings of GLOREAM Symposium, 2001, Wengen, Switserland, 2002.

Mathijsen, J., van Arkel, F., Schaap, M., Weijers, E., ten Brink, H., and Denier van der Gon, H.: Nationaal onderzoeksprogramma vergroot kennis over fijn stof, LUCHT, 1, 2009 (in Dutch).

Morino, Y., Kondo, Y., Takegawa, N., Miyazaki, Y., Kita, K., Komazaki, Y., Fukuda, M., Miyakawa, T., Moteki, N., and Worsnop, D. R.: Partitioning of $\mathrm{HNO} 3$ and particulate nitrate over Tokyo: Effect of vertical mixing, J. Geophys. Res.-Atmos., 111, D15215, doi:10.1029/2005JD006887, 2006.

Moya, M., Ansari, A. S., and Pandis, S. N.: Partitioning of nitrate and ammonium between the gas and particulate phases during the 1997 IMADA-AVER study in Mexico City, Atmos. Environ., 35, 1791-1804, 2001.

Nenes, A., Pilinis, C., and Pandis, S. N.: Continued Development and Testing of a New Thermodynamic Aerosol Module for Urban and Regional Air Quality Models, Atmos. Environ., 33, 1553-1560, 1999.

Pakkanen, T. A., Hillamo, R. E., Aurela, M., Andersen, H. V., Grundahl, L., Ferm, M., Persson, K., Karlsson, V., Reissell, A., Royset, O., Floisand, I., Oyola, P., and Ganko, T.: Nordic intercomparison for measurement of major atmospheric nitrogen species, J. Aerosol Sci., 30, 247-263, 1999.

Perrino, C., Ramirez, D., and Allegrini, I.: Monitoring acidic air pollutants near Rome by means of diffusion lines: development 
of a specific quality control procedure, Atmos. Environ., 35, 331-341, 2001

Putaud, J., Raesa, F., Van Dingenen, R., Bruggemann, E., Facchini, M., Decesari, S., Fuzzi, S., Gehrig, R., Hueglin, C., Laj, P., Lorbeer, G., Maenhaut, W., Mihalopoulos, N., Mueller, K., Querol, X., Rodriguez, S., Schneider, J., Spindler, G., ten Brink, H., Torseth, K., and Wiedensohler, A.: A European aerosol phenomenology-2:chemical characteristics of particulate matter at kerbside, urban, rural and background sites in Europe, Atmos. Environ., 38, 2579-2595, 2004.

Russchenberg, H. W. J., Bosveld, F., Swart, D., ten Brink, H., de Leeuw, G., Uijlenhoet, R., Arbesser-Rastburg, B., van der Marel, H., Ligthart, L., Boers, R., and Apituley, A.: Groundbased atmospheric remote sensing in The Netherlands; European outlook, IEICE Transactions on Communications, Vol.E88-B(6), 22522258, doi:10.1093/ietcom/e88-b.6.2252, 2005.

Schaap, M., Mueller, K., and ten Brink, H. M.: Constructing the European aerosol nitrate concentration field from quality analysed data, Atmos. Environ., 36, 1323-1335, 2002.

Schaap, M., Spindler, G., Schulz, M., Acker, K., Maenhaut, W., Berner, A., Wieprecht, W., Streit, N., Mueller, K., Brüggemann, E., Putaud, J.-P., Puxbaum, H., Baltensperger, U., and ten Brink, H. M.: Artefacts in the sampling of nitrate studied in the "INTERCOMP" campaigns of EUROTRAC-AEROSOL, Atmos. Environ., 38, 6487-6496, 2004a.

Schaap, M., van Loon, M., ten Brink, H. M., Dentener, F. J., and Builtjes, P. J. H.: Secondary inorganic aerosol simulations for Europe with special attention to nitrate, Atmos. Chem. Phys., 4, 857-874, doi:10.5194/acp-4-857-2004, 2004b.

Schaap, M., Denier Van Der Gon, H. A. C., Dentener, F. J., Visschedijk, A. J. H., van Loon, M., Ten Brink, H. M., Putaud, J.-P., Guillaume, B., Liousse, C., and Builtjes, P. J. H.: Anthropogenic Black Carbon and Fine Aerosol Distribution over Europe, J. Geophys. Res., 109, D18201, doi:10.1029/2003JD004330, 2004c.

Schaap, M., Sauter, F., and Builtjes, P.: On the direct aerosol forcing of nitrate over Europe: Simulations with the new LOTOSEUROS model, in: Developments in Environmental Science, Air Pollution Modeling and its Application XVIII, 6, edited by: Borrego C. and Renner E., 582-591, doi:10.1016/S14748177(07)06510-2, 2007.

Schaap, M., Timmermans, R. M. A., Sauter, F. J., Roemer, M., Velders, G. J. M., Boersen, G. A., Beck, J. P., and Builtjes, P. J. H.: The LOTOS-EUROS model: description, validation and latest developments, Int. J. Environ. Pollut., 32, 270-290, 2008.

Simpson, D., Fagerli, H., Jonson, J. E., Tsyro, S., Wind, P., and Tuovinen, J.-P.: Transboundary Acidification, Eutrophication and Ground Level Ozone in Europe, Part 1: Unified EMEP Model Description, EMEP Report 1/2003, Norwegian Meteorological Institute, Oslo, Norway, 2003.

Simpson, D., Fagerli, H., Hellsten, S., Knulst, J. C., and Westling, O.: Comparison of modelled and monitored deposition fluxes of sulphur and nitrogen to ICP-forest sites in Europe, Biogeosciences, 3, 337-355, doi:10.5194/bg-3-337-2006, 2006.

Slanina, J., ten Brink, H. M., Otjes, R. P., Even, A., Jongejan, P., Khlystov, A., Waijers-Ijpelaan, A., Hu, M., and Lu, Y.: Continuous analysis of nitrate and ammonium in aerosols by the Steam Jet Aerosol Collector (SJAC), Atmos. Environ., 35, 2319-2330, 2001.

Stern, R., Builtjes, P., Schaap, M., Timmermans R., Vautard, R.,
Hodzic, A., Memmesheimer, M., Feldmann, H., Renner, E., Wolke, R., and Kerschbaumer, A.: A model inter-comparison study focussing on episodes with elevated $\mathrm{PM}_{10}$ concentrations, Atmos. Environ., 42, 4567-4588, 2008.

Takahama, S., Wittig, A. E., Vayenas, D. V., Davidson, C. I., and Pandis, S. N.: Modeling the diurnal variation of nitrate during the Pittsburgh Air Quality Study, J. Geophys. Res.-Atmos., 109, D16S06, doi:10.1029/2003JD004149, 2004.

Tang, Y. S., Simmons, I., van Dijk, N., Di Marco, C., Nemitz, E., Dämmgen, U., Gilke, K., Djuricic, V., Vidic, S., Gliha, Z., Borovecki, D., Mitosinkova, M., Hanssen, J. E., Uggerud, T. H., Sanz, M. J., Sanz, P., Chorda, J. V., Flechard, C. R., Fauvel, Y., Ferm, M., Perrino, C., and Sutton, M. A.: European scale application of atmospheric reactive nitrogen measurements in a lowcost approach to infer dry deposition fluxes, Agriculture, Ecosystems and Environment, 133, 183-195, 2009.

Ten Brink, H. M., Kruisz, C., Kos, G. P. A., and Berner, A.: Composition/size of the light-scattering aerosol in the Netherlands, Atmos. Environ., 31, 3955-3962, 1997.

Ten Brink, H. M., Otjes, R. P., Jongejan, P., and Slanina, S.: An instrument for semi-continuous monitoring of the size-distribution of nitrate, ammonium, sulphate and chloride in aerosol, Atmos. Environ., 41, 2768-2779, 2007.

Thomas, R. M., Trebs, I., Otjes, R., Jongejan, P. A. C., ten Brink, H., Phillips, G., Kortner, M., Meixner, F. X., and Nemitz, E.: An automated analyzer to measure surface-atmosphere exchange fluxes of water soluble inorganic aerosol compounds and reactive trace gases, Environ. Sci. Technol., 43, 1412-1418, 2009.

Twigg, M., Di Marco, C. F., Phillips, G. J., Jones, M. R., Cape, J. N., Leith, I., Simmons, I., Leeson, S., and Nemitz, E.: Longterm quasi-real time measurements of inorganic reactive gases and aerosols at the Scottish EMEP Supersite, to be submitted to Atmos. Chem. Phys. Discuss., 2011.

UNECE: EMEP monitoring strategy, UNECE report/EB.AIR/GE.1/2009/15, available at: http://www.unece.org/ env/lrtap/welcome.html, 2009.

van Loon, M., Vautard, R., Schaap, M., Bergström, R., Bessagnet, B., Brandt, J., Builtjes, P. J. H., Christensen, J. H., Cuvelier, K., Graf, A., Jonson, J. E., Krol, M., Langner, J., Roberts, P., Rouil, L., Stern, R., Tarrasón, L., Thunis, P., Vignati, E., White, L., and Wind P.: Evaluation of long-term ozone simulations from seven regional air quality models and their ensemble average, Atmos. Environ., 41, 2083-2097, 2007.

Vecchi, R., Valli, G., Fermo, P., D’Alessandro, A., Piazzalunga, A., and Bernardoni, V.: Organic and inorganic sampling artefacts assessment, Atmos. Environ., 43, 1713-1720, doi:10.1016/j.atmosenv.2008.12.016, 2009.

Visschedijk, A. J. H., Zandveld, P., and Denier van der Gon, H. A. C.: A high resolution gridded European emission database for the EU integrated project GEMS, TNO-report, 2007-AR0233/B, Utrecht, The Netherlands, 2007.

von Bobrutzki, K., Braban, C. F., Famulari, D., Jones, S. K., Blackall, T., Smith, T. E. L., Blom, M., Coe, H., Gallagher, M., Ghalaieny, M., McGillen, M. R., Percival, C. J., Whitehead, J. D., Ellis, R., Murphy, J., Mohacsi, A., Pogany, A., Junninen, H., Rantanen, S., Sutton, M. A., and Nemitz, E.: Field inter-comparison of eleven atmospheric ammonia measurement techniques, Atmos. Meas. Tech., 3, 91-112, doi:10.5194/amt-3-91-2010, 2010.

Weber, R., Orsini, D., Duan, Y., Baumann, K., Kiang, C. S., 
Chameides, W., Lee, Y. N., Brechtel, F., Klotz, P., Jongejan, P., Brink ten, H., Slanina, J., Boring, C. B., Genfa, Z., Dagupta, P., Hering, S., Stolzenburg, M., Dutcher, D. D., Edgerton, E., Hartsell, B., Solomon, P., and Tanner, R.: Intercomparison of near real-time monitors of $\mathrm{PM}_{2.5}$ Nitrate and sulfate at the EPA Atlanta Supersite, J. Geophys. Res., 108, 8421-8433, 2003.

Weijers, E. P., Sahan, E., ten Brink, H. M., Schaap, M., Matthijsen, J., Otjes, R., and van Arkel, F.: Presence and characteristics of secondary inorganic aerosols in the Netherlands; measurements and modelling. Netherlands Research Program on Particulate Matter (BOP), PBL Report 500099006, PBL, Bilthoven, the Netherlands, www.pbl.nl, 2010.

Weijers, E. P., Schaap, M., Nguyen, L., Matthijsen, J., Denier van der Gon, H. A. C., ten Brink, H. M., and Hoogerbrugge, R.: Anthropogenic and natural constituents in particulate matter in the Netherlands, Atmos. Chem. Phys., 11, 2281-2294, doi:10.5194/acp-11-2281-2011, 2011.
Yu, S., Dennis, R., Roselle, S., Nenes, A., Walker, J., Eder, B., Schere, K., Swall, J., and Robarge, W.: An assessment of the ability of three-dimensional air quality models with current thermodynamic equilibrium models to predict aerosol $\mathrm{NO}_{3}$, J. Geophys. Res.-Atmos., 110, D07S13, doi:10.1029/2004JD004718, 2005.

Zhang, J., Charmeides, W. L., Weber, R., Cass, G., Orsini, D., Edgerton, E., Jongejan, P., and Slanina, J.: An evaluation of the thermodynamic equilibrium assumption for fine particulate composition: Nitrate and ammonium during the 1999 Atlanta Supersite experiment, J. Geophys. Res.-Atmos., 108, 8414, doi:10.1029/2001JD001592, 2003.

Zimmerling, R., Dammgen, U., and Behrend, U.: Konzentrationen versauernd und eutrophierend wirkender Spurengase und Aerosol-Bestandteile in Nordost-Brandenburg, Wissenschaftliche Mitteilungen der Bundesforschungsanstalt $\mathrm{f}$ ur Landwirtschaft, Sonderheft 213, Landbauforschung Volkernrode, Braunschweig, Germany, 2000. 